\title{
A Fast-acting Option in Severe Hypertriglycidemia-induced Pancreatitis in an Adolescent with Type 2 Diabetes: Insulin Infusion
}

The Editor,

Sir,

A fast-acting option in severe hypertriglycidemia-induced pancreatitis in an adolescent with type 2 diabetes: insulin infusion.

The risk of pancreatitis increases when triglyceride levels rise above $1000 \mathrm{mg} / \mathrm{dl}$. This requires particular attention in subjects with type 2 diabetes, which is accompanied by elevated triglyceride levels in one in every two patients. Apheresis, a treatment option in pancreatitis developing secondary to hypertriglyceridemia, is expensive and not available in every center (1). Another option, heparin administration, may result in rebound hypertriglyceridemia (2). Continuous insulin infusion has been successfully and effectively applied in hypertriglyceridemia (3).

A 15.5-year-old female patient presented with abdominal pain and accompanying nausea and vomiting over the previous 2 days. At physical examination weight was $58.5 \mathrm{~kg}$ ( $70^{\text {th }}$ percentile), height $155 \mathrm{~cm}\left(13^{\text {th }}\right.$ percentile $)$ and body mass index 24.35 ( $85^{\text {th }}$ percentile). At biochemical examination glucose level was $393 \mathrm{mg} / \mathrm{dl}$, sodium $122 \mathrm{mmol} / \mathrm{l}$ (136-145), potassium $3.9 \mathrm{mmol} / \mathrm{l}(3,5-5,1)$, chloride $92 \mathrm{mmol} / \mathrm{l}$ (90-110), urea $13 \mathrm{mg} / \mathrm{dl}(15-44)$, creatinine $0.37 \mathrm{mg} / \mathrm{dl}(0,57-1,1)$, ALT $32 \mathrm{u} / 1$ (0-55), amylase $56 \mathrm{u} / 1$ (25-125), lipase 195u/l (8-78), triglyceride $6695 \mathrm{mg} / \mathrm{dl}(0-150)$, cholesterol $949 \mathrm{mg} / \mathrm{dl}$ (0-200) and HDL cholesterol $18 \mathrm{mg} / \mathrm{dl}(40-60)$.

Urine and blood were negative for ketone. HBA1C was $12 \%$. Family members and the patient were screened for lipoprotein lipase mutation and no mutation was detected. Abdominal tomography was compatible with acute pancreatitis. Autoantibodies investigated 
in terms of autoimmune diabetes were negative. The patient was assessed as type 2 diabetes mellitus and acute pancreatitis induced by hypertriglyceridemia. Oral intake was discontinued due to pancreatitis, the stomach was decompressed and somatostatin infusion was started. Insulin infusion was started at 0.08 units $/ \mathrm{kg}$ per hour for hyperglycemia and hypertriglyceridemia. At the 14th h of infusion, triglyceride levels decreased by $80 \%$ (1110 $\mathrm{mg} / \mathrm{dl})$. After $72 \mathrm{~h}$ the patient progressed from continuous insulin infusion to subcutaneous insulin therapy (fig.1). The requirement for subcutaneous insulin was gradually reduced and eliminated within 2 months. Values investigated again at the $3^{\text {rd }}$ month were blood sugar 90 $\mathrm{mg} / \mathrm{dl}$, insulin $10.53 \mu \mathrm{IU} / \mathrm{mL}, \mathrm{C}$ peptide $3.17 \mathrm{ng} / \mathrm{ml}(0.9-7.1)$ and HBA1C \%5,5, and there was no dyslipidemia.

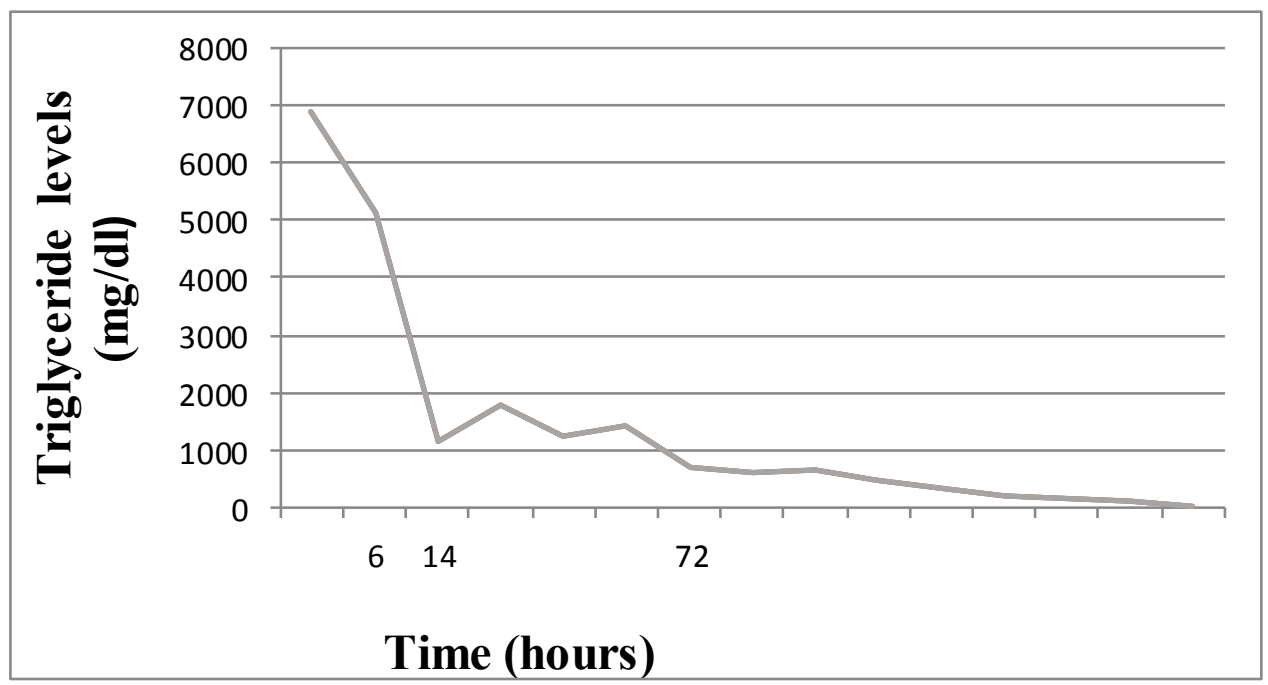

Figure1: Triglyceride levels throughout observation are shown in the figure. 
There are no randomized studies comparing these treatment modalities, and authors generally recommend apheresis and insulin therapy, alone or in combination (4). In terms of time to response to treatment, one study in which insulin infusion was applied alone reported a $40 \%$ fall in triglyceride levels compared to median triglyceride levels within a mean $24 \mathrm{~h}$, and a $50 \%$ decrease in the first $48 \mathrm{~h}$ (3). A level of $65.8 \%$ in $2 \mathrm{~h}$ after a single session of apheresis has been reported (5). A complication-free $80 \%$ decrease in triglyceride level was observed in the first $14 \mathrm{~h}$ in our patient. In conclusion, continuous insulin infusion alone in patients with severe hypertriglyceridemia is a rapid and effective treatment modality in the reduction of triglyceride levels.

Keywords: Hypertriglycidemia, insulin, pancreatitis

A Üstyol ${ }^{1}$, ME Atabek ${ }^{1}$,HA Yüksekkaya ${ }^{2}$, M Gümüş ${ }^{2}$

From: ${ }^{1}$ Department of Pediatric Endocrinology and Diabetes, and ${ }^{2}$ Department of Pediatric Gastroenterology, School of Medicine, Necmettin Erbakan University, Konya, Turkey.

Correspondence: Dr A üstyol, Necmettin Erbakan Universitesi Meram Tip Fakultesi, Cocuk Sagligi ve Hastaliklari, 42080 Konya- TURKEY. Fax: 00. 90. 332. 223 6181, e-mail: aladr79@yahoo.com.tr 


\section{REFERENCES}

1. Ewald N, Kloer HU. Treatment options for severe hypertriglyceridemia (SHTG): the role of apheresis. Clin Res Cardiol Suppl 2012; 7: 31-5.

2. Weintraub $\mathrm{M}$, Rassin $\mathrm{T}$, Eisenberg $\mathrm{S}$, et al. Continuous intravenous heparin administration in humans causes a decrease in serum lipolytic activity and accumulation of chylomicrons in circulation. J Lipid Res. 1994; 35: 229-38.

3. Henderson SR, Maitland R, Mustafa OG, Miell J, Crook MA, Kottegoda SR. Severe hypertriglyceridaemia in Type 2 diabetes mellitus: beneficial effect of continuous insulin infusion. QJM. 2013; 106: 355-9.

4. Bota VM. Urgent apheresis combined with insulin infusion in hypertriglyceridemiainduced acute pancreatitis. Am J Emerg Med. 2013; 31: 452.e1-2. doi: 10.1016/j.ajem.2012.06.027. Epub 2012 Aug 31.

5. Pang J, Chan DC, Watts GF. Origin and therapy for hypertriglyceridaemia in type 2 diabetes. World J Diabetes 2014; 5: 165-75. 